\title{
Redescription of Temnocephala iheringi (Platyhelminthes: Temnocephalida) based on specimens from Pomacea canaliculata (Mollusca: Ampullariidae) of the state of Rio Grande do Sul, Brazil: the possible type host and type locality
}

\author{
Samantha A. Seixas; José F. R. Amato \& Suzana B. Amato
}

Departamento de Zoologia, Instituto de Biociências, Universidade Federal do Rio Grande do Sul. Caixa Postal 15014, 91501-970 Porto Alegre, Rio Grande do Sul, Brazil.

E-mail: samantha_bio@yahoo.com.br; josefelipeamato@gmail.com; sbamato@ufrgs.br

\begin{abstract}
The original description of Temnocephala iheringi Haswell, 1893 was based on specimens collected by Hermann von Ihering from undetermined ampullariid apple snails, which at that time were identified as Ampullaria sp., and sent to William H. Haswell, with the type locality simply indicated as Brazil. The type specimens studied by Haswell were not found in the scientific collections of Brazil, Europe or Australia, and should be considered lost. In 1941, Pereira \& Cuocolo collected specimens from apple snails, identified as Pomacea lineata (Spix in Wagner, 1827), at two localities (Guaicurús and Salobra) in the state of Mato Grosso do Sul, central Brazil. These specimens could not be located either and should, thus, be considered lost as well. Pomacea canaliculata (Lamarck, 1822), the main host of T. iheringi in southern Brazil, is known to have a geographical distribution that reaches Uruguay and $400 \mathrm{~km}$ beyond the province of Buenos Aires, Argentina. Three hundred and one mollusks were collected from 1999 to 2007. Temnocephalans found in the pallial cavity presented a greenish body pigmentation (adults) and lacked eye pigment of any color, including the red-eye pigment, typical of Neotropical species of Temnocephala Blanchard, 1849; straight cirrus, with a thick band at base of the introvert' swelling; and a single, circular, asymmetric vaginal sphincter, wider in diameter in the posterior portion. As the species occurs concurrently with two other species, at least in P. canaliculata from Rio Grande do Sul, the eggs of $T$. iheringi could not be reliably distinguished. A redescription of the species is provided. A comparison of data from the present work with those of earlier papers published on T. iheringi from Argentina showed that the Argentinean specimens had the smallest measurements.
\end{abstract}

KEY WORDS. Ectocommensals; mollusks; Neotropical Region; South America; taxonomy.

Temnocephala iheringi Haswell, 1893 is the most studied ectosymbiont turbellarian species found on ampullariid apple snails. It was originally described based on specimens collected by Hermann von Ihering from an undetermined species of Ampullaria (currently Pomacea Perry, 1810) and type locality was generically reported as "Brazil" (HAswell 1893). Hermann von Ihering was a German zoologist that moved to Brazil in 1880 (ODEвREсht 2009), where he decided to establish residence in the state of Rio Grande do Sul (Fig. 1). He lived in several localities, mostly around Laguna dos Patos, and one of these localities is the probable type locality of $T$. iheringi. There are many records of this species in the literature, all based on specimens fixed with the usual compression method. Temnocephala iheringi was reported as an ectosymbiont of Pomacea lineata (Spix in Wagner, 1827) (Pereira \& Cuocolo 1941), Asolene platae (Maton, 1811) (Hyman 1955), Pomacea canaliculata (Lamarck, 1822) (DAmborenea
1992, Damborenea \& Cannon 2001), and Pomella megastoma (Sowerby, 1825) (Damborenea et al. 1997). Di Persia \& Radici de CuRA (1973) included T. iheringi in the study of trophic relationships between ectosymbionts and ampullariidean snails; FLECHER \& PONCE DE LEÓN (1983) studied the regeneration capacity of $T$. iheringi; and GonzÁlez et al. (1987) analyzed chromosome differences between T. iheringi and Temnocephala haswelli Ponce de León, 1989. Moretto \& Durquet (1977) and Moretto (2001) used this species in their study about the reproductive system of temnocephalans, whereas Damborenea $(1996,1998)$ and DAmborenea et al. (2006) studied the patterns of distribution and abundance of this and other temnocephalan species in Argentina. The function of the Haswell glands has been elucidated, in part, by Volonterio \& Ponce de León (2004), who described the ultrastructure of these glands in T. iheringi and T. haswelli. A complete study of the biotic and abiotic factors affecting the distri- 
bution and abundance of temnocephalans was performed using infrapopulations of $T$. iheringi from $P$. canaliculata. This study extended the known distribution of the species to more than $400 \mathrm{~km}$ south of province of Buenos Aires, the southernmost natural limit of the host species (MARTín et al. 2005).

Four species of Temnocephala Blanchard, 1849 are presently known from ampullariid snails: T. iheringi (HASwELL 1893), Temnocephala rochensis Ponce de León, 1979 (Ponce De León 1979), T. haswelli (Ponce DE LEÓN 1989), and Temnocephala lamothei Damborenea \& Brusa, 2008 (DAMBORENEA \& BRUSA 2008). Only T. iheringi has been recorded in Brazil. Haswell (1893) did not specify a type locality, indicating Brazil as the origin of the specimens. Pereira \& Cuocolo (1941) redescribed the species for the first time, but based on ectosymbiont specimens from Pomacea lineata (Spix in Wagner, 1827) collected in Salobra and Guaicurús, both localities in the state of Mato Grosso, now Mato Grosso do Sul. Hyman (1955) made an unsatisfactory redescription of $T$. iheringi based on specimens from Argentina, collected from ampullariid snails identified as A. platae, from Arroyo Malabrigo, province of Santa Fe. This was the first record of T. iheringi in another genus of Ampullariidae and it was also the first record of the species outside of Brazil, although the correct identification of the mollusk cannot be confirmed. Damborenea et al. (1997), in a paper about the benthonic fauna of Isla Martín García, province of Buenos Aires, Argentina, recorded the species in a new host, Asolene megastoma Sowerby, 1825 (= currently Pomella megastoma). Temnocephala iheringi was also recorded by Dioni (1967) but this record is incorrect since he described the cirrus with strong curvature ("fuerte curvature" on page 483) and illustrated (figs 7a, b and c, page 480) a curved cirrus.

To date, there are no records of any species of Temnocephala from correctly identified ampullariid snails in precisely identified geographical localities in the state of Rio Grande do Sul, southern Brazil. Even with several published records of this species, a complete study of $T$. iheringi (showing several specific characters) through an array of special techniques, as we have been doing since 2003, has not yet been undertaken.

\section{MATERIAL AND METHODS}

Three hundred and one specimens of $P$. canaliculata were collected between 1999 and 2007 using dip nets and/or large sand sieves and transported live to the Laboratório de Helmintologia, Universidade Federal do Rio Grande do Sul (UFRGS). Porto Alegre, Brazil. Live temnocephalans were obtained from hosts collected from Rio Jacuí, at Ilha da Pintada $\left(30^{\circ} 02^{\prime} 23^{\prime \prime} S\right.$, $\left.051^{\circ} 25^{\prime} 49^{\prime \prime} \mathrm{W}\right)$, municipality of Porto Alegre; Ponta do Ceroula $\left(30^{\circ} 15^{\prime} 07.51^{\prime \prime} \mathrm{S}, 051^{\circ} 16^{\prime} 49.55^{\prime \prime} \mathrm{W}\right)$, municipality of Barra do

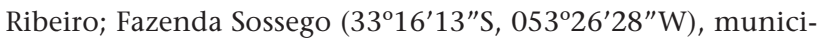
pality of Santa Vitória do Palmar; Praia Florida $\left(30^{\circ} 15^{\prime} 54^{\prime \prime} \mathrm{S}\right.$, $\left.051^{\circ} 32^{\prime} 25^{\prime \prime} \mathrm{W}\right)$, municipality of Guaíba; channels around rice plots located $5 \mathrm{~km}$ west of Interstate Highway BR-290, near the locality of Arrozeira ( $\left.30^{\circ} 01^{\prime} 36^{\prime \prime} \mathrm{S}, 051^{\circ} 22^{\prime} 42^{\prime \prime} \mathrm{W}\right)$, municipality of Eldorado do Sul; Rio Cachoeira 'Barragem do Cerrito' (Tributary of Rio Maquiné) (29 $34^{\prime} 15^{\prime \prime}$ S, $\left.050^{\circ} 16^{\prime} 51^{\prime \prime} \mathrm{W}\right)$, District of Barra do Ouro, municipality of Maquiné; and Sava Clube (30 $06^{\prime} 09^{\prime \prime}$ S, $\left.051^{\circ} 15^{\prime} 57.5^{\prime \prime} \mathrm{W}\right)$, Lago Guaíba, municipality of Porto Alegre. All the above municipalities are in the state of Rio Grande do Sul, Brazil. These areas are included in the Atlantic Rain Forest (Brazilian Atlantic Forest Biome).

Some helminths taken from live hosts were studied and photomicrographed alive or fixed in cold AFA under slight cover slip pressure (the traditional procedure). Some specimens were stained in Delafield's hematoxylin (Амато \& Амато 2005) or aceto-carmine/fast green (GAligher \& Kozloff 1971, Humason 1972), cleared in cedar oil, and mounted in Canada balsam for internal morphometry. To preserve body shape and for the purpose of scanning electron microscopy (SEM), some specimens were flooded with hot, phosphate buffered 10\% formalin (HF) (Амато et al. 2006). The morphology of the dorsolateral 'excretory' syncytial epidermal plates (DLSPs) was studied in specimens fixed with silver nitrate (SN) (RomeIs 1948, Joffe et al. 1995) or observed with SEM (Амато et al. 2005, Амато et al. 2007). Cirrus morphology (Fig. 2a) has been studied after micro dissection and mounting in Faure's medium (CANNON 1993, Cannon \& Sewell 1995, Sewell et al. 2006). The distribution of rhabditogenic and disc glands was studied by clearing juvenile specimens in lactophenol (Амато \& Амато 2005). Photomacrographs of hosts showing the egg distribution and the helminth pigmentation were taken with a Zeiss Stemi SV-6 stereomicroscope (Figs 3-5, 7, and 8). Photomicrographs were taken with a Zeiss Axiolab microscope with phase contrast (or just the phase contrast condenser), and a Leica DMR Hc microscope with Nomarski's differential interference contrast (DIC) prisms, or a Jeol (JSM-6060) SEM. Drawings were made with a drawing tube on a Nikon E-200 microscope. The photographic images and scanned line drawings were prepared using Adobe's Photoshop CS2 ${ }^{\circledR}$. Measurements are in micrometers $(\mu \mathrm{m})$ unless otherwise indicated; ranges are followed by the arithmetic mean, the number of specimens measured for a given character (when different than 30), and the standard deviation values (between parentheses). Some internal organs were not measured following the suggestion by SEwELL et al. (2006).

Voucher specimens and slides containing individual cirri of T. iheringi were deposited in the "Coleção Helmintológica do Instituto Oswaldo Cruz" (CHIOC), Rio de Janeiro, RJ, Brazil. Other voucher specimens stained in Delafield's hematoxylin were deposited in the invertebrate collection of the "División Zoología Invertebrados, Museo de La Plata" (MLP), La Plata, Buenos Aires, Argentina. Some mollusk hosts were deposited in the "Coleção Malacológica do Instituto Oswaldo Cruz" (CMIOC). The remaining host specimens and temnocephalans are in the host and helminth collections of the "Coleção Helmintológica do Laboratório de Helmintologia, Departamento de Zoologia", UFRGS, Porto Alegre, RS, Brazil. 

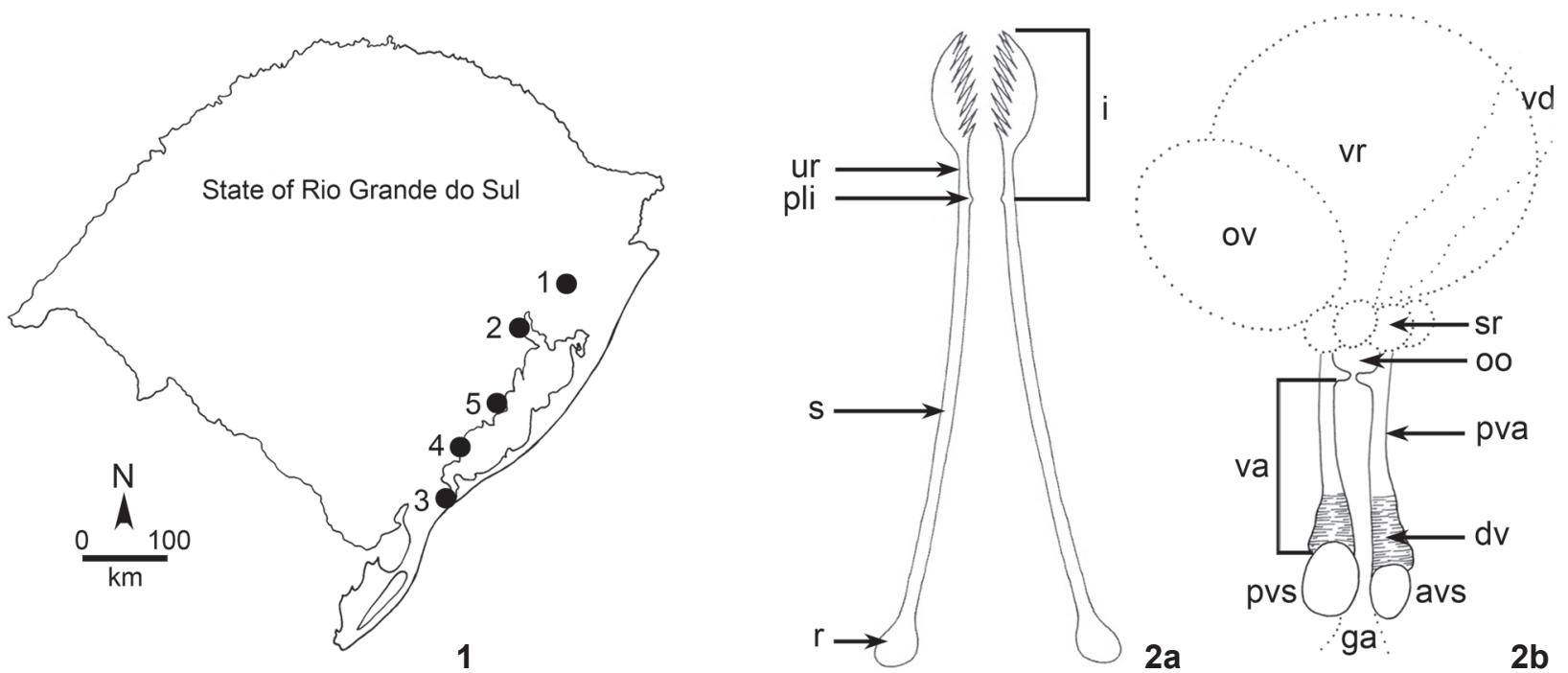

Figures 1-2. (1) Map of the state of Rio Grande do Sul, Brazil, indicating the localities where Dr Hermann von Ihering lived: 1) Village of Taquara [1880-1883]; 2) Civil Parish of Pedras Brancas, today City of Guaíba [1883-1884]; 3) City of Rio Grande [1884-1885]; 4) Village of São Lourenço do Sul [1885]; 5) Civil Parish of Nossa Senhora das Dores de Camaquã, today City of Camaquã [1885-1892]. (2) Terminology used to describe the reproductive system: (2a) diagram of cirrus, introvert (i), proximal limit of introvert marked by 'lateral spikes' (pli), unspined proximal region (ur), shaft (s), and shaft's rim (r); (2b) diagram of the distal female reproductive system, genital atrium (ga), vitellarium duct (vd), vesicula resorbens (vr), ovary (ov), seminal receptacles (sr), ootype (oo), vagina (va), proximal vagina (pva), distal vagina (dv), anterior vaginal sphincter (avs), and posterior vaginal sphincter (pvs).

\section{TAXONOMY}

\section{Temnocephala iheringi Haswell, 1893 Figs 6-36}

Redescription. Based on 340 specimens collected; 237 whole mounted adult specimens; 103 juveniles; 8 specimens mounted on stubs for SEM; 19 dissected cirri mounted in Faure; 12 mounted specimens fixed in $\mathrm{SN}$; 30 specimens fixed in AFA under slight cover slip pressure measured: External characteristics. Body (without tentacles) (Fig. 6) 1935-3199 $(2437,288)$ long, 513-1797 $(1358,237)$ wide; adhesive disk ventral, sub-terminal, partially covered by the body (Figs 11, 14, 17, and 20) 410-790 $(581,92)$ long, 580-980 $(701,101)$ wide; disc peduncle $80-300$ $(160, \mathrm{n}=26,51)$ long, $190-370(284,52)$ wide; ratio between maximum cirrus length/adhesive disk diameter 3.4: 1. Greenish body pigmentation well pronounced in live adult specimens (Figs 7 and 8). Red pigmentation of the eyes absent (observations made on live specimens) (Fig. 9). Two dorsolateral, elliptical epidermal 'excretory' syncytial plates (DLSPs) with anterior portion narrower than posterior (Figs 20 and 21), extending from basis of first and fifth tentacles; left plate 260-450 $(352, \mathrm{n}=12,59)$ long, 150-240 (189, $\mathrm{n}=12,25)$ wide; right plate 270-420 (346, $\mathrm{n}$ $=12$, 52) long, $150-250(198, \mathrm{n}=12$, 30) wide; ratio between length of DLSPs/total body length, without tentacles, 4.9: 1. Excretory pore (nephridiopore) approximately at the center of each syncytial plate (Figs 20 and 21).
Alimentary system. Mouth surrounded by a small muscular sphincter (Figs 6, 17, and 31), between first and second thirds of body; pharynx longer than wide, $360-553(445,133)$ long, 316-691 $(409,112)$ wide, with a large sphincter (Fig. 31); esophageal glands surrounding esophagus at base (Fig. 31); intestine saccular (Fig. 17), inconspicuous septations in juveniles and adults; intestinal walls thick.

Glands. Rhabditogenic glands small, numerous, with a granular appearance, forming bunches (average of 22 cells), in lateral fields of body (Figs 13 and 15), 35-77 $(50,11)$ in diameter, extending on the sides of the intestinal sac, with conspicuous ducts (Figs 13 and 15), best observed in juvenile specimens cleared in lactophenol, before complete development of vitellarium. Two groups of four Haswell glands (Figs 12 and 17) showing little affinity with hematoxylin, in front of the brain transverse band (Fig. 17), diameter of the largest cell 50$97(66, \mathrm{n}=24,15)$. Disc glands between adhesive disc and genital complex forming two lateral bunches extending from posterior testis to margin of adhesive disc (Fig. 16), including two pairs of large, round, more central cells (paranephrocytes?), 37-72 $(53,9)$ in diameter (Figs 14 and 16).

Reproductive system. Female. Vitellarium arborescent, completely covering intestine in dorsal region (Figs 6, 10, and 17), partially in ventral region, with branches that almost meet each other; vagina long, narrow (sometimes distended - Fig. 32), with distal portion muscular (Figs 18 and 33 - white arrows), 

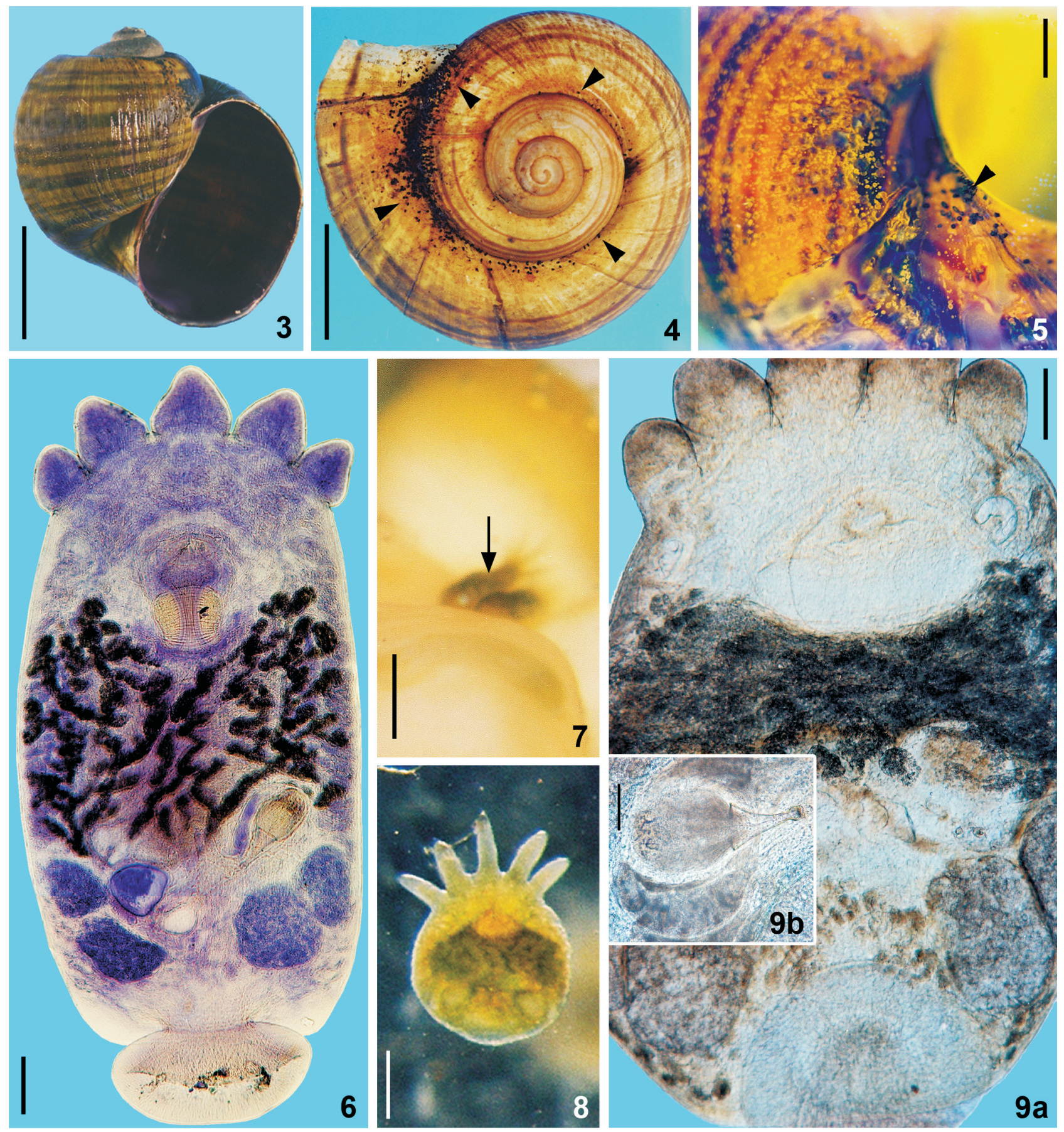

Figures 3-9. Pomacea canaliculata and Temnocephala iheringi. (3-5) Pomacea canaliculata: (3) ventral view, bar $=2 \mathrm{~cm}$; (4) apical view, showing the increase in numbers of temnocephalan eggs, as the host grows documenting the growth of the infrapopulation (head arrows), bar $=1 \mathrm{~cm}$; (5) umbilicus showing eggs (head arrow), bar $=0.5 \mathrm{~cm}$. (6-9) Temnocephala iheringi: (6) adult specimen, stained in Delafield's hematoxylin, bar $=100 \mu \mathrm{m}$; (7) two live specimens (arrow) in the pallial cavity of a snail recently euthanized, bar $=4 \mathrm{~mm}$; (8) live, adult specimen showing the greenish body pigment, bar $=1 \mathrm{~mm}$; (9a) live, adult specimen under the light microscope showing lack of the red pigment of the eyes, bar $=250 \mu \mathrm{m}$; (9b) Inset, showing the terminal male genitalia with the straight cirrus in higher magnification, typical of $T$. iheringi, bar $=100 \mu \mathrm{m}$. 

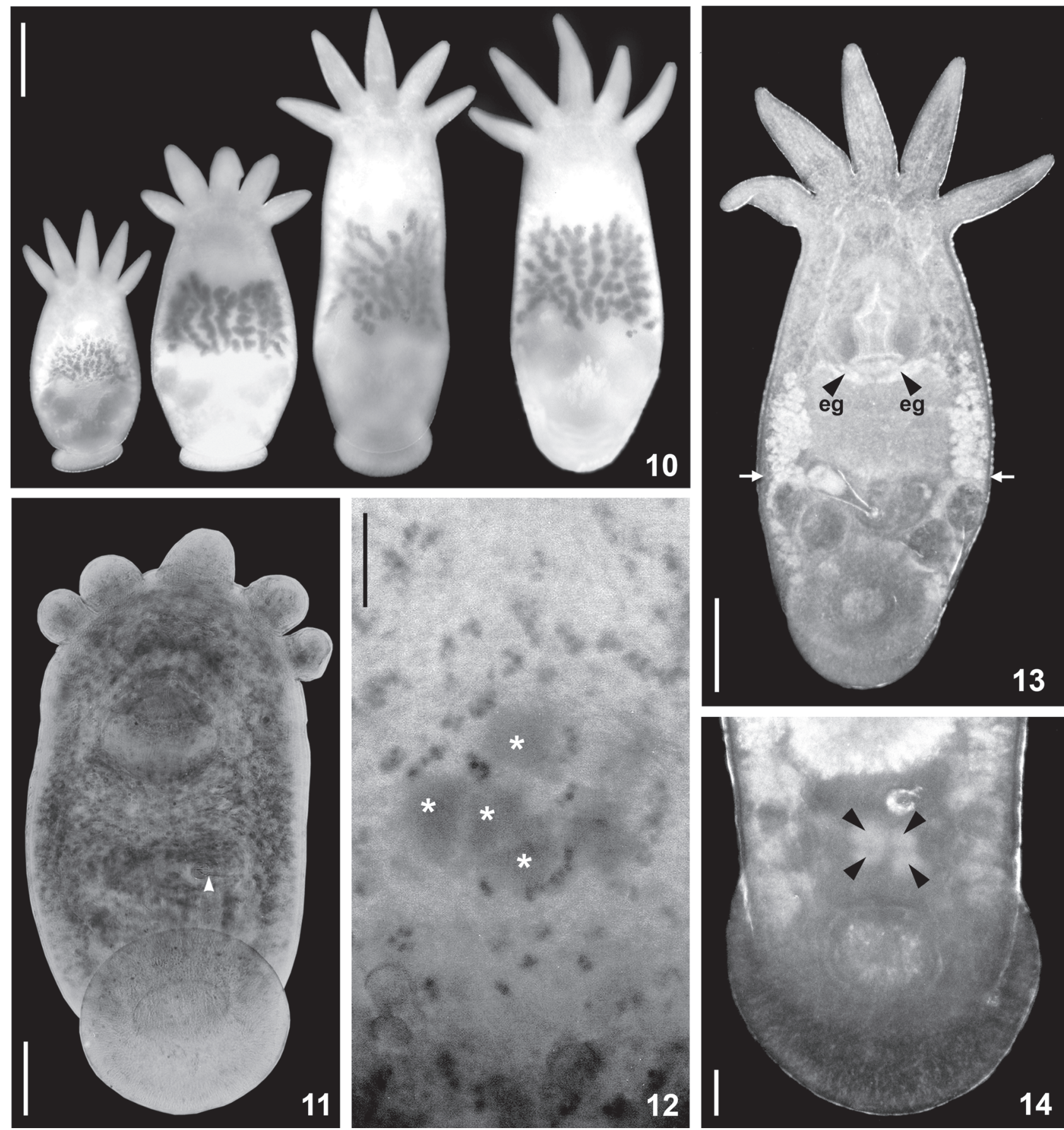

Figures 10-14. Temnocephala iheringi: (10) specimens fixed with hot formalin (HF), showing variations in body shape and absence of eyes, bar $=500 \mu \mathrm{m} ;(11)$ recently hatched juvenile, ventral view, showing the incipient straight cirrus (white head arrow), bar = $100 \mu \mathrm{m}$; (12) left group of Haswell glands (stars), bar $=50 \mu \mathrm{m}$; (13-14) specimens cleared in lactophenol; (13) entire specimen showing the limit between the anterior rhabditogenic glands and the posterior disc glands (white arrows), black head arrows (eg) indicating the esophageal glands, bar $=250 \mu \mathrm{m}$; (14) posterior half of the body, showing two pairs of large disc glands (paranephrocytes?) (black head arrows), bar $=50 \mu \mathrm{m}$. 


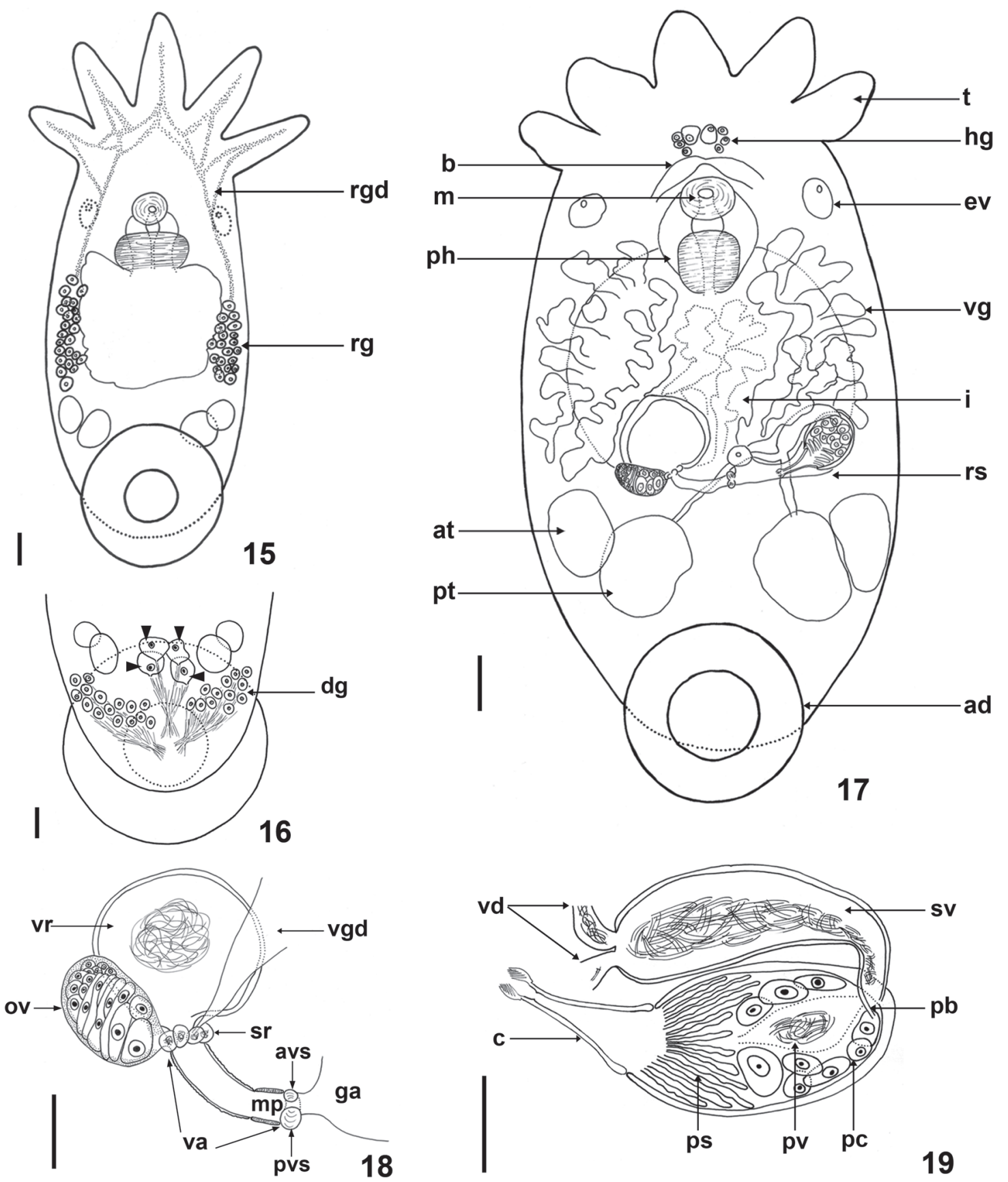

Figures 15-19. Temnocephala iheringi: (15) juvenile, ventral view, showing rhabditogenic glands (rg) extending along sides of intestinal $\mathrm{sac}$, and its ducts (rgd) entering tentacles, bar $=100 \mu \mathrm{m} ;(16)$ dorsal view showing posterolateral disk glands (dg) and the two pairs of large disk glands (paranephrocytes?) (black head arrows), bar $=50 \mu \mathrm{m} ;(17)$ incomplete diagram of adult specimen fixed with cold AFA and slight cover slip pressure showing tentacles ( $t$ ), Haswell glands (hg), brain transverse band (b), mouth (m), pharynx (ph) excretory vesicles (ev), vitellarium (v), intestinal sac (i), reproductive system ( $r s)$, anterior testes (at), posterior testes (pt), adhesive disk (ad), bar = $250 \mu \mathrm{m}$; (18) female reproductive complex, showing vesicula resorbens (vr), ovary (ov), seminal receptacles (sr), vagina (va), distal vagina with muscular portion ( $\mathrm{mp}$ ), anterior (avs) and posterior (pvs) portions of the vaginal sphincter, genital atrium (ga), bar $=100$ $\mu \mathrm{m} ;(19)$ male reproductive complex: vasa deferentia (vd), seminal vesicle (sv), prostatic bulb (pb), prostatic cells (pc), prostatic vesicle (pv), prostatic secretion (ps), cirrus (c), bar $=100 \mu \mathrm{m}$. 
$110-230(163,29)$ long, 50-160 $(84,22)$ maximum width; muscular sphincter circular, small, asymmetrical (Figs 18, and 33-34 - black arrow), 50-70 $(61,5)$ in diameter; $15-27(22,3)$ diameter of anterior portion, $27-40(32,3)$ diameter of posterior portion; vesicula resorbens usually full of sperm (Figs 18 and 33), 157-410 $(251,57)$ long, 75-460 $(302,86)$ wide; wall thickness 2-15 $(8,3)$.

Male. Seminal vesicle (Figs 19, 35-36) 242-372 (298, 19) long, 25-117 $(65,19)$ wide; wall thickness 2-10 $(4,2)$; prostatic bulb with muscular wall (Figs 19, 35-36), 115-255 $(182,19)$ long, 130-235 $(169,19)$ wide; wall thickness 5-15 $(10,3)$; prostatic vesicle present (Figs 19 and 35-36). Cirrus short, straight (Figs
19 and 24) 170-215 (193, $\mathrm{n}=10,15)$ long, shaft 120-157 (140, n $=10,14)$ long, shaft base $102-142(122, \mathrm{n}=10,14)$ wide; introvert 47-60 $(53, \mathrm{n}=10,4)$ long, $20-27(22, \mathrm{n}=10,2)$ wide at base; maximum introvert width at level of swelling, 30-47 (35, $\mathrm{n}=10$, 5). Conspicuous thickening on the base of the swelling (Figs 25 and 30). Introvert' swelling with approximately 28 longitudinal rows of long, fine spines and approximately 7 spines per row (Figs 27-29). Ratio between total body length without tentacles/ total length of cirrus 12.6: 1 ; ratio between total length of cirrus/maximum width of shaft's base 1.6: 1 ; ratio between total length of cirrus/total length of introvert 3.6: 1.
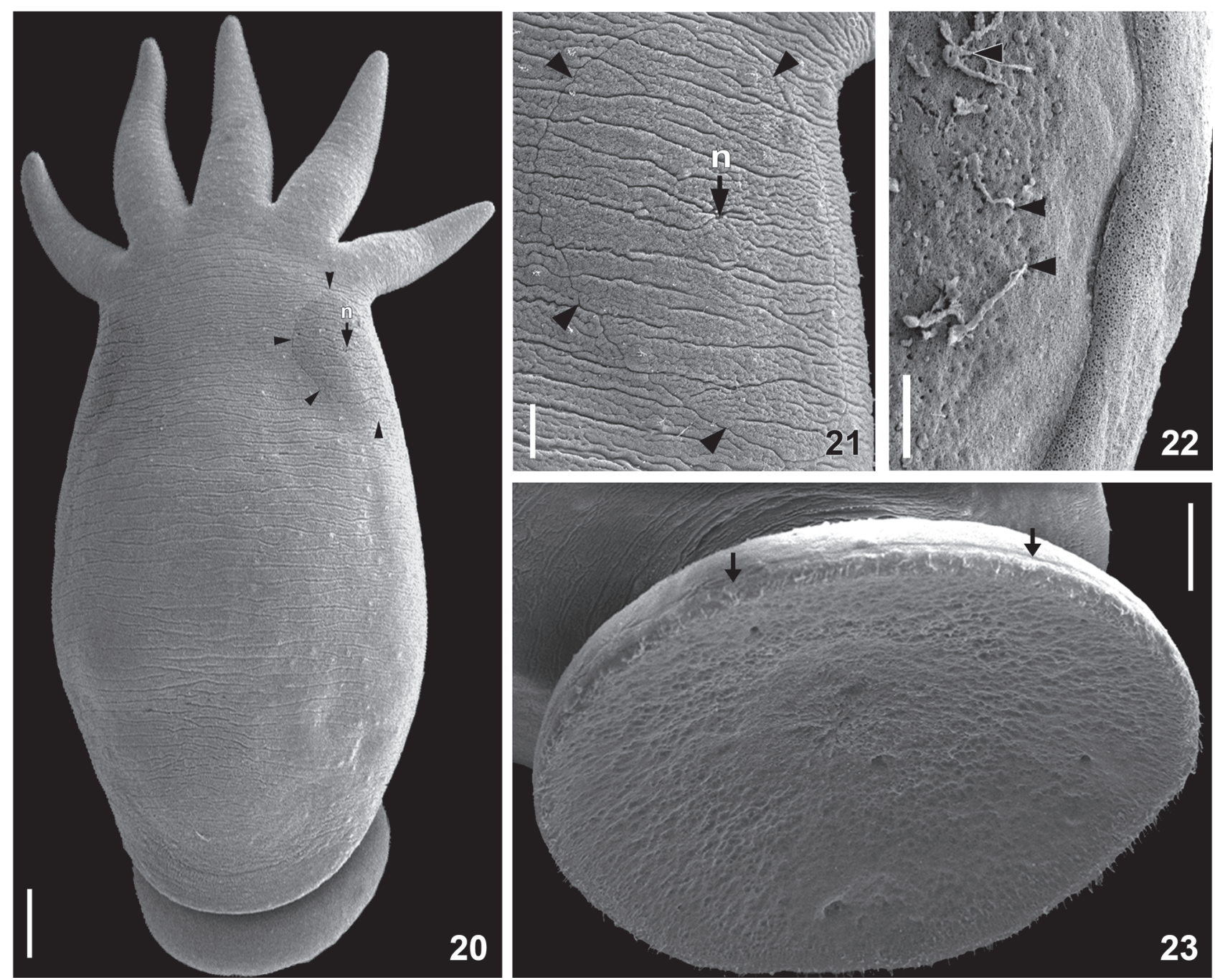

Figures 20-23. Temnocephala iheringi, SEM: (20) adult, dorsal view, showing right dorsolateral 'excretory' syncytial plate (head arrows) and nephridiopore $(\mathrm{n})$, bar $=100 \mu \mathrm{m} ;(21)$ higher magnification of the right syncytial plate, showing the off-center nephridiopore (n), and the limits of the plate (head arrows), bar $=25 \mu \mathrm{m}$; (22) higher magnification of the adhesive disk syncytial plate, showing adhesive secretions produced by disc glands oozing from pores (head arrows), bar $=50 \mu \mathrm{m}$; (23) adhesive disk syncytial plate, limits of the plate (arrows), bar $=50 \mu \mathrm{m}$. 


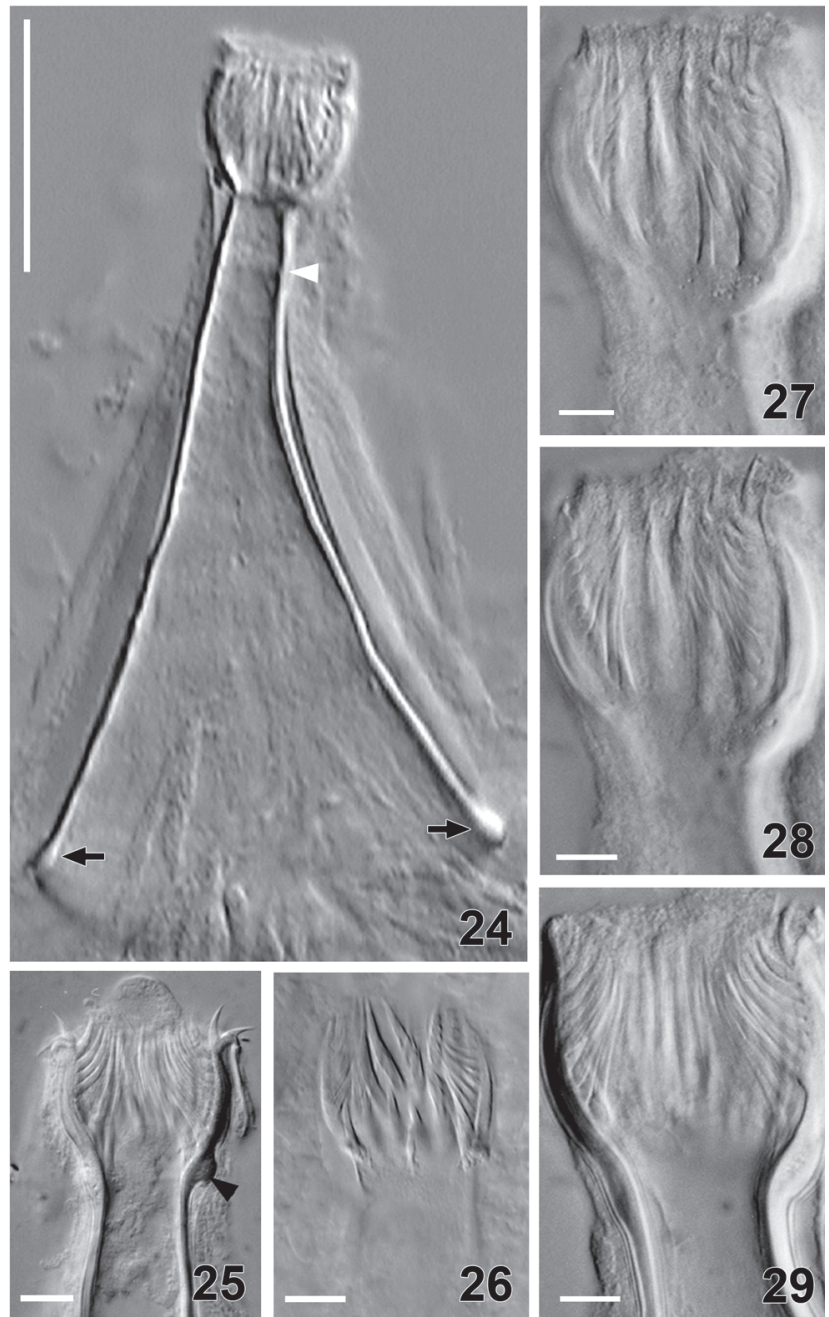

Figures 24-29. Temnocephala iheringi, photomicrographs of cirri, seen with Nomarski's DIC microscopy: (24) entire cirrus, showing the proximal limit of introvert (white head arrow), and the shaft rim (black arrows) typical of adult worms, bar $=50 \mu \mathrm{m}$; (25) introvert partially everted, showing the conspicuous thickening on the base of the swelling (head arrow), bar $=10 \mu \mathrm{m}$; (26) cirrus of juvenile, bar $=5 \mu \mathrm{m}$; (27-29) introvert seen in different focusing planes, from the top of the internal surface to mid-section, $\operatorname{bar}=10 \mu \mathrm{m}$.

\section{Taxonomic summary}

Type host and type locality. Ampullaria (= Pomacea) sp. (Gastropoda, Caenogastropoda, Ampullariidae), Brazil (HAswelL 1893).

Possible type host and type locality. Pomacea canaliculata (Lamarck, 1822) from one of the several localities (Fig. 1) where Hermann von Ihering lived in Rio Grande do Sul (Taquara, Guaíba, Rio Grande, São Lourenço or Camaquã), most probably Camaquã.

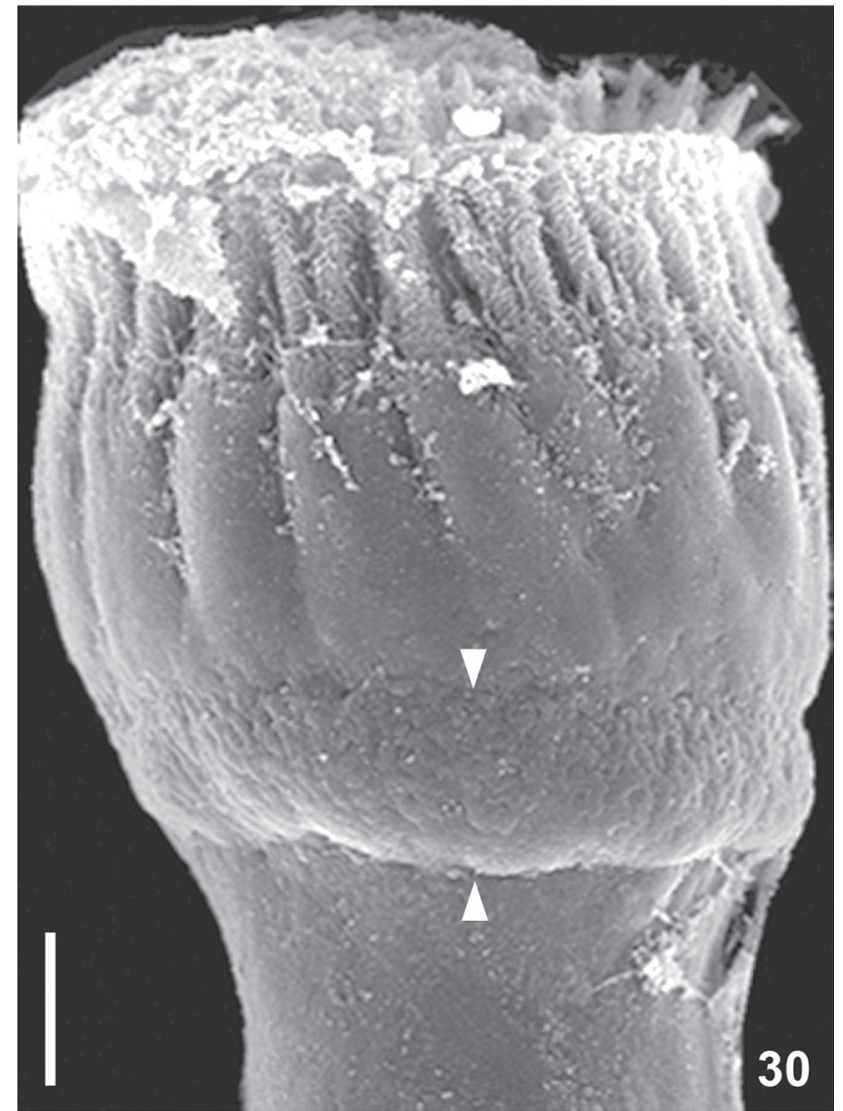

Figure 30. Temnocephala iheringi, SEM photomicrograph of the introvert, showing the conspicuous thickening on the base of the swelling (head arrows), bar $=10 \mu \mathrm{m}$.

Other hosts and localities. Pomacea lineata (Spix in Wagner, 1827), Salobra and Guaicurús, state of Mato Grosso do Sul, Brazil (Pereira \& Cuocolo 1941); Asolene platae (Maton, 1809), Río San Javier, province of Santa Fe, Argentina (Hyman 1955); Pomacea canaliculata (Lamarck, 1822), Parana medio, Argentina (Di Persia \& RAdici de CuRA 1973); ruta Interbalnearia (km 21), Canelones, Uruguay (Flecher \& Ponce de León 1983); Avenida Italia (km 21.5), Canelones, Uruguay (González et al.1987); Laguna Don Felipe, province of Santa Fe, and Punta Lara, Canteras de Los Talas, Arroyo Doña Flora, Punta Indio, province of Buenos Aires, Argentina (DAmborenea 1992); Arroyo Zapata, Magdalena, province of Buenos Aires, Argentina (Damborenea \& Cannon 2001); Pomella megastoma (Sowerby, 1825), Río de La Plata, province of Buenos Aires, Argentina (Damborenea et al. 1997, Damborenea et al. 2006, Vega et al. 2006). Other localities (present work). Pomacea canaliculata (Lamarck, 1822), Ilha da Pintada and Sava Clube, Lago Guaíba, municipality of Porto Alegre, RS, Brazil; Fazenda Sossego, municipality of Santa Vitória do Palmar, RS; Ponta do Ceroula, municipality of Barra do Ribeiro, RS, Brazil; Praia Florida, Lago 

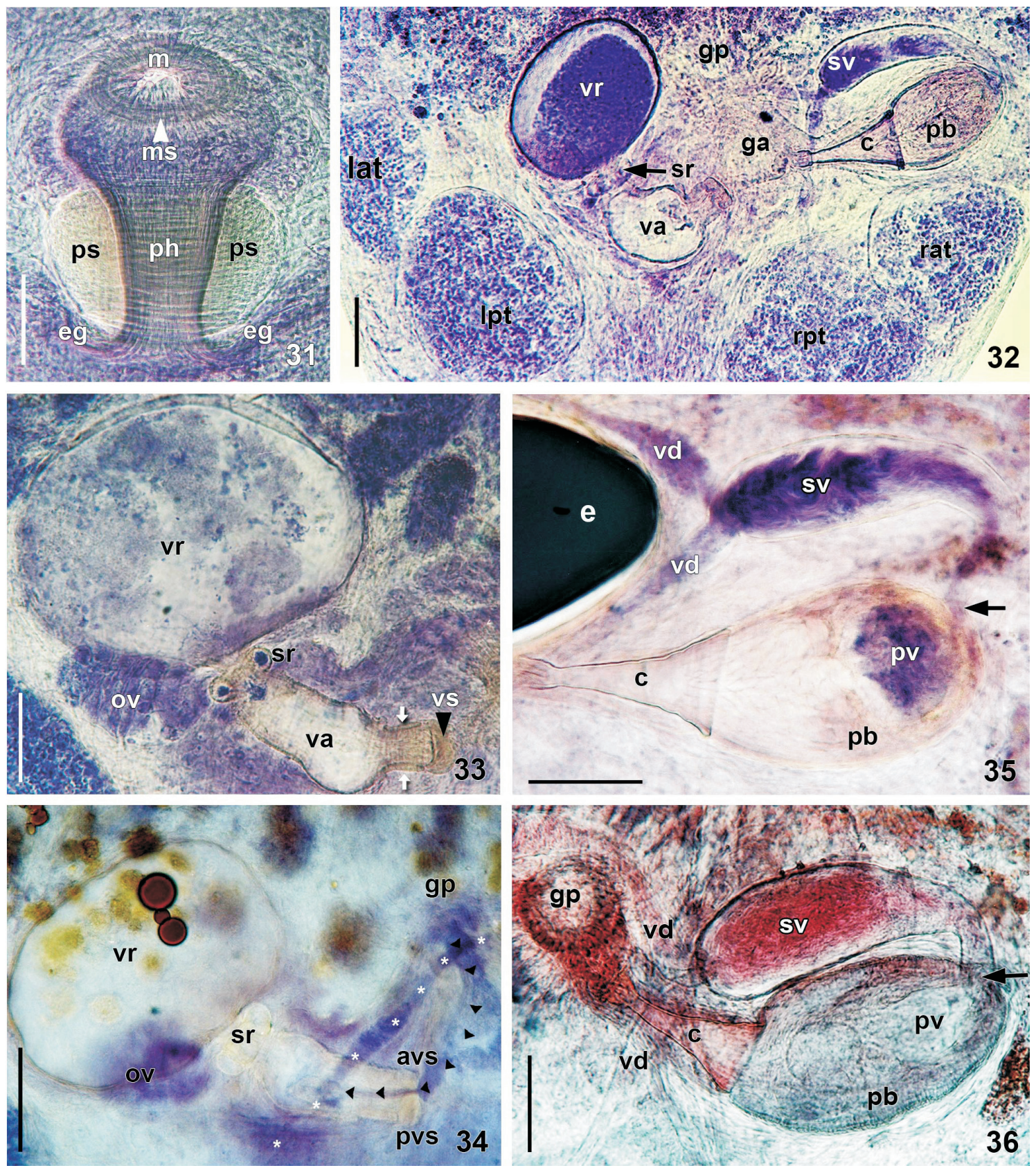

Figures 31-36. Temnocephala iheringi, selected characters in the internal anatomy: (31) mouth (m), mouth sphincter (ms), pharynx (ph), pharyngeal sphincter (ps), esophageal glands (eg), bar $=100 \mu \mathrm{m} ;(32)$ reproductive zone: left anterior testis (lat), left posterior testis (lpt), right posterior testis (rpt), right anterior testis (rat), genital pore (gp), genital atrium (ga), cirrus (c), prostatic bulb (pb), seminal vesicle (sv), vagina (va), seminal receptacles (sr), vesicula resorbens (vr), bar $=100 \mu \mathrm{m}$; (33-34) partial female reproductive complex (33) vesicula resorbens (vr), ovary (ov), seminal receptacles (sr), vagina (va), distal vagina with muscular wall (arrows), vaginal sphincter (vs) (head arrow), bar $=100 \mu \mathrm{m}$; (34) different focusing plane: vesicula resorbens (vr), ovary (ov), seminal receptacles (sr), anterior (avs) and posterior (pvs) portions of the circular vaginal sphincter, genital pore (gp), vasa deferentia (stars), trajectory of spermatozoids toward the vagina (head arrows), bar $=250 \mu \mathrm{m}$; (35-36) partial male reproductive complex, bar $=100 \mu \mathrm{m}$ : (35) vasa deferentia (vd), seminal vesicle (sv), prostatic bulb (pb), prostatic vesicle with spermatozoids (pv), cirrus (c), egg (e); (36) specimen stained with aceto-carmine/fast-green: genital pore (gp), vasa deferentia (vd), seminal vesicle (sv) and its insertion point (arrow) with the prostatic bulb (pb), prostatic vesicle (pv), cirrus (c). 
Guaíba, municipality of Guaíba, RS, Brazil; Arrozeira, municipality of Eldorado do Sul, RS, Brazil; Barra do Ouro, municipality of Maquiné, RS, Brazil.

Site of infestation. Adults and juveniles in mantle cavity, eggs in umbilicus, suture, and spire, sometimes in larger numbers in the body whorl of the shell; never present on the operculum.

Helminth specimens deposited. CHIOC No 37192, 37197, 37198, 37199 - voucher specimens fixed in AFA, stained in Delafield's hematoxylin; CHIOC No 37194 - voucher specimen (juvenile) fixed in AFA, stained in Delafield's hematoxylin; CHIOC No 37193, 37196 - voucher specimens fixed in AFA, stained in aceto-carmine/fast green; $\mathrm{CHIOC} \mathrm{N}^{\circ} 37200 \mathrm{a}$ - voucher specimen fixed in SN; CHIOC $\mathrm{N}^{\circ} 37200 \mathrm{~b}$ - cirri from voucher specimens, in Faure; MLP Nos 5915 - 5920 - voucher specimens fixed in AFA and stained in Delafield's hematoxylin.

Host specimens were deposited in the CMIOC under the $\mathrm{N}^{\circ} 5820$.

Other helminth specimens examined. Specimens from $P$. canaliculata, collected in Argentina, deposited in the Invertebrate Collection Museo de La Plata (MLP N ${ }^{\circ}$ 3118, Arroyo Miguelin, Punta Lara; MLP Nº 3119 and 3121, Canteras de Berisso, Los Talas, Berisso; MLP N ${ }^{\circ} 3120$, Arroyo Doña Flora, Ensenada).

Remarks. Examination of a large number of specimens of T. iheringi collected from the probable type locality consistently showed that they did not present red-eye pigmentation when observed alive (Figs 8 and 9a). The adhesive secretions produced by the disc glands oozing from pores in the ventral surface of the disk can be observed for the first time in figure 22 . The vagina has a muscular wall on the distal portion (Figs 18 and 33), difficult to observe, as it has the same thickness as the middle and proximal portions. The vaginal sphincter has the anterior portion with a smaller average diameter than the posterior portion (Fig. 18). The apparent large variation of the shaft's base width of the cirrus may represent only intra-specific variation. These differences are not related to collection localities, thus excluding the possibility that these variations would be related to a given component population of each collection area. Further, another peculiar aspect never before recorded for the cirrus of this species is the circular 'thickening' at the base of the introvert' swelling, only visualized in samples prepared in Faure's medium and observed with SEM (Figs 25 and 30). The eggs of $T$. iheringi were not measured because this species, in Rio Grande do Sul, has, to date, always been found in concurrent infestations with either T. haswelli or T. rochensis making it impossible, at present, to separate the eggs of $T$. iheringi which are always found in the same areas of the shell.

\section{DISCUSSION}

Based on historical documentation (Anonymous 1930, Odebrecht 2009), Herman von Ihering lived in Rio Grande do Sul, Brazil until 1892, when he moved to São Paulo, SP, Brazil. Sometime before 1893 (publication year of the original description) he collected mollusk specimens that were received by
Haswell through Charles Chilton of New Zealand. A plausible possibility of a collection locality is the area of the delta of Rio Camaquã, where von Ihering lived for seven years (1885-1892), on an island known then as "Ilha do Doutor" (Doctor's Island is one of the three islands: Quebra Mastro, Santo Antônio, and Três Bocas, in the delta of Rio Camaquã, presently in the municipality of Camaquã).

Remarks by Haswell (1893) suggest that the type locality of $T$. iheringi could only be the state of Rio Grande do Sul. As far as we know, only in Rio Grande do Sul is the host $P$. canaliculata found with concurrent infestations by two species of temnocephalan. In his remarks he reports receiving a sample which included specimens of distinct species. Although he did not realize that he had more than one species in the sample, he reported that: " $T$. Jheringi was found by Dr v. Jhering in Brazil in the branchial cavity of a species of Ampullaria. It differs from T. Semperi Weber: (1) in the absence of eyes; (2) in the form of the cirrus, which is very much wider at its proximal end, curved instead of straight, and with a terminal introvert of a different form; (3) in the first pair of testes being placed much further back; and (4) in the shape of the ovary." Haswell (1893), however, described and illustrated (Plate XIII, Fig. 19 and Plate XV, Fig. 2) the cirrus straight. The curved cirrus, with a much wider shaft base belonged to a species that would only be described in 1989, by Ponce de León in Uruguay. Several characters described by Haswell (1893) such as testes position and vitellarium distribution, agree with the observations in the present study. The lack of the red pigmentation of the eyes, if it existed, could not have been observed by him, since he received specimens already fixed (probably in some grade of ethanol), which, as we now know, dilutes the red pigment.

The distribution of $T$. iheringi is restricted presently to Brazil (Haswell 1893, Baer 1931, Pereira \& Cuocolo 1941), Argentina (Hyman 1955, Damborenea 1992, Damborenea et al. 1997, 2006, Damborenea \& Cannon 2001, Martín et al. 2005), and Uruguay (Flecher \& Ponce de León 1983, González et al.1987).

Pereira \& Cuocolo (1941) justified their redescription of the species based on the fact that in the original description of Haswell (1893) the precise type locality was not defined. These authors attributed the report of absence of the red pigmentation of the eyes to a technical deficiency, as well as, the "absence" of seminal vesicle. In fact, Haswell (1893) did not recognize the seminal vesicle and mistook it for the prostatic bulb. The absence of red pigmentation of the eyes in T. iheringi (Figs 8-10), indicated by Haswell, was confirmed in the present work, although he received dead specimens, possibly in ethanol (which, as mentioned above, dilutes the red pigment). The Brazilian populations of $T$. iheringi are the only ones (up to now) in the Neotropical Region without such pigmentation. This aspect calls for careful examination of live specimens.

Hyman (1955) also confirmed the lack of the red-eye pigmentation, although she also did not work with live specimens. This author described the bulb of the cirrus as "a prostatic vesicle 
with a muscular wall containing a mass of elongated cells around a central lumen". This type of prostatic bulb has been observed in the present study in which the central lumen in the proximal portion of the bulb dilates forming a prostatic vesicle (Fig. 35) that also contained spermatozoids.

DAMBOREnEA (1992) stated that the prostatic glands are external to the bulb and that they surround the cirrus, free in parenchyma, disagreeing with HyMan (1955), who studied longitudinal and frontal histological sections and affirmed that there was no evidence to postulate external prostatic glands. The statement by Damborenea also agrees with the drawings made by Haswell (1893). In this respect, Damborenea may be right.

Damborenea \& Cannon (2001) reviewed the Neotropical species of Temnocephala. It was the first work to show the cirrus and DLSPs of several species in detail. The diagrammatic representation of the shape of the DLSPs of T. iheringi is similar to that found in the present study, although the greater richness of observations (SN and SEM) has shown details not revealed by DAMBORENEA \& CANNON (2001), including the pores with secretions oozing out of the adhesive disk's syncytial plate (Fig. 22). These authors considered that all Neotropical species had red-eye pigmentation (examined alive by them) defining this character as an autapomorphy of Temnocephala. The absence of this pigment is so uncommon that there is only one species (Temnohaswellia pearsoni Sewell, Cannon \& Bray, 2006) without eye pigmentation. This putative autapomorphy should be re-evaluated since, as in the present study, other species or populations in other ampullariid may be found to lack red-eye pigmentation.

A vesicle was observed inside the prostatic bulb, which due to its localization was called 'prostatic vesicle' (Fig. 35). This same vesicle was observed and illustrated in the description of Temnocephala mertoni Volonterio, 2007, ectocommensal of Aegla platensis Schmitt, 1942, by VOLONTERIO (2007), who called it 'contractile vesicle'.

Comparing measurements of the specimens of $T$. ihering $i$ published to date (Tab. I), there are appreciable differences between the Brazilian and the Argentinean specimens, mainly in the total body length. This character was measured in almost all previous studies (even in the oldest ones), but has no taxonomic value. The Argentinean specimens showed the smallest measurements when compared to the Brazilian specimens. This could be indicative of intra-specific variation between the Brazilian and Argentinean populations, or may be the representation of a latitudinal cline, making it necessary that, in the future, a complete study should also be conducted with specimens collected in different latitudes in Argentina.

Table I. Measurements of $T$. iheringi from the literature and from the present work. (1) PeReIRA \& Cuocolo (1941), range; (2) DamboreneA (1992), \# mean; (3) Damborenea et al. (1997), \# mean; (4) Hyman (1955), \# mean + tentacle; (5)Damborenea \& Cannon (2001), \# mean; (6) Present work Mean, range.

\begin{tabular}{|c|c|c|c|c|c|c|}
\hline \multirow{2}{*}{ Characters } & \multicolumn{6}{|c|}{ Measurements from the literature } \\
\hline & 1 & 2 & 3 & 4 & 5 & 6 \\
\hline Body length (without tentacles)* & $2.4-3.48$ & 1.81 & 2 & 1.3 & - & $2.43(1.93-3.19)$ \\
\hline Maximum width* & $1.1-1.85$ & 1.274 & 1.2 & - & - & $1.35(0.51-1.79)$ \\
\hline Adhesive disk diameter* & $0.49-0.70$ & 0.506 & 0.62 & - & - & $0.7(0.53-0.98)$ \\
\hline Pharynx length* & $0.38-0.60$ & - & - & - & - & $0.44(0.36-0.55)$ \\
\hline Pharynx width* & $0.28-0.43$ & - & - & - & - & $0.4(0.31-0.69)$ \\
\hline Posterior testis length* & $0.20-0.34$ & - & - & - & - & $0.33(0.24-0.49)$ \\
\hline Anterior testis length* & $0.18-0.30$ & - & - & - & - & $0.3(0.19-0.45)$ \\
\hline Anterior testis width* & $0.16-0.24$ & - & - & - & - & $0.22(0.11-0.31)$ \\
\hline Seminal vesicle length & $260-380$ & 221.71 & 218.97 & - & - & $298(242-372)$ \\
\hline Seminal vesicle width & $60-70$ & 107.54 & 50.89 & - & - & $65(25-117)$ \\
\hline Prostatic bulb length & $220-240$ & 131.79 & 148.6 & - & - & $182(115-255)$ \\
\hline Prostatic bulb width & $120-160$ & 126.15 & 127.24 & - & - & $169(130-235)$ \\
\hline Cirrus length & $160-180$ & 157.06 & 153 & - & 157 & 193 \\
\hline Shaft width base & - & 68.92 & 100.8 & - & 69 & 122 \\
\hline Ovary length & - & 142.02 & 101.79 & - & - & 109 \\
\hline Ovary width & - & 89.43 & 123.47 & - & - & 169 \\
\hline Body length/Adhesive disk diameter & - & - & $3.2: 1$ & - & - & $3.5: 1$ \\
\hline Body length/Cirrus length & - & - & 13.1:1 & - & - & $12.6: 1$ \\
\hline
\end{tabular}

$(-)$ Characters not measured by authors, $\left(^{*}\right)$ measurements in millimeters, (\#) Argentinean specimens. 


\section{ACKNOWLEDGEMENTS}

The authors are grateful to Jorge E. de A. Mariath and Rinaldo P. dos Santos, Laboratório de Anatomia Vegetal, Instituto de Biociências, UFRGS, for the permission to use the Leica DMR Hc microscope to make the DIC photomicrographs; to Centro de Microscopia Eletrônica (CME), UFRGS; to Maria Cristina Damborenea, Curator, Invertebrate Collection at Museo de La Plata (MLP), for the loan of some Argentinean specimens of $T$. iheringi from $P$. canaliculata and for receiving Brazilian specimens of T. iheringi, collected and prepared by us, for deposit; to Silvana A. Thiengo for the deposit number of $P$. canaliculata specimens in the Coleção Malacológica do Instituto Oswaldo Cruz and for calling our attention to the fact that molecular biology studies are under way to clarify the existence of a possible canaliculata complex of species; to Rodrigo Ponce de León, for kindly providing a copy of Haswell's important paper; to Ludwig Buckup for valuable information on the life of Hermann von Ihering and for loaning literature; to Kátia M. B. Ferreira, Librarian, Seção de Referência e Informação, Museu Paulista da Universidade de São Paulo, São Paulo, for kindly preparing the bibliographic citation about Hermann von Ihering; to Philip J. Scholl for kindly reviewing the English version of the manuscript; and to Lauren B. Pordany for her expertise in staining the specimens and for the continuous help in the laboratory.

\section{LITERATURE CITED}

Aмато, J.F.R. \& S.B. Амато. 2005. New species of Temnocephala Blanchard (Platyhelminthes, Temnocephalida) ectosymbiont on giant water bugs, Belostoma spp. (Hemiptera, Belostomatidae) from southern Brazil. Revista Brasileira de Zoologia 22 (1): 107-118.

Амato, J.F.R.; S.B. Амato \& S.A. Seixas. 2005. Temnocephala lutzi Monticelli (Platyhelminthes, Temnocephalida) ectosymbiont on two species of Trichodactylus Latreille (Crustacea, Decapoda, Trichodactylidae) from southern Brazil. Revista Brasileira de Zoologia 22 (4): 1085-1094.

Амato, J.F.R.; S.B. Амato \& S.A. Seixas. 2006. A new species of Temnocephala Blanchard (Platyhelminthes, Temnocephalida) ectosymbiont on Trichodactylus fluviatilis Latreille (Crustacea, Decapoda, Trichodactylidae) from southern Brazil. Revista Brasileira de Zoologia 23 (3): 796-806.

Aмato, J.F.R.; S.A. Seixas \& S.B. Амato. 2007. A new species of Temnocephala Blanchard (Platyhelminthes, Temnocephalida) ectosymbiont on creeping water bugs, Cryphocricos granulosus De Carlo (Hemiptera, Naucoridae) from southern Brazil. Revista Brasileira de Zoologia 24 (4): 1043-1051.

Anonymous. 1930. Hermann von Ihering. Obituaries. The Auk 47: 452-453.

BAER, J.G. 1931. Étude monographique du groupe des Temnocephales. Bulletin Biologique de la France et de la Belgique 1: 1-57.

Cannon, L.R.G. 1993. New temnocephalans (Platyhelminthes): ectosymbionts of freshwater crabs and shrimps. Memoirs of the Queensland Museum 33 (1): 17-40.

Cannon, L.R.G. \& K.B. Sewell. 1995. Craspedellinae Baer, 1931 (Platyhelminthes: Temnocephalida) ectosymbionts from the branchial chamber of Australian crayfish (Crustacea: Parastacidae). Memoirs of the Queensland Museum 38 (2): 397-418.

Damborenea, M.C. 1992. Especies de Temnocephala (Platyhelminthes, Temnocephalidae) de crustáceos y moluscos de la Argentina. Iheringia, Série Zoologia, 72: 3-21.

Damborenea, M.C. 1996. Patrones de distribucion y abundancia de Temnocephala iheringi (Platyhelminthes: Temnocephalidae) en una población de Pomacea canaliculata (Mollusca: Ampullariidae). Gayana, Zoología, 60 (1): 1-12.

Damborenea, M.C. 1998. Distribution patterns of temnocephalids commensal with Crustacea and Mollusca from Argentina. Hydrobiologia 383 (1-3): 269-274.

Damborenea, M.C. \& F. Brusa. 2008. A new species of Temnocephala (Platyhelminthes, Temnocephalida) commensal of Pomella megastoma (Mollusca, Ampullariidae) from Misiones, Argentina. Revista Mexicana de Biodiversidad 79 (Supl.): 1S-7S.

Damborenea, M.C.; F. Brusa \& A. Paola. 2006. Variation in worm assemblages associated with Pomacea canaliculata (Caenogastropoda, Ampullariidae) in sites near the Río de la Plata estuary, Argentina. Biocell 30 (3): 457-468.

Damborenea, M.C. \& L.R.G. CAnnon. 2001. On neotropical Temnocephala (Platyhelminthes). Journal of Natural History 35 (12): 1103-1118.

Damborenea, M.C.; I.I. César \& L.C. Armendáriz. 1997. Especies de Temnocephala (Platyhelminthes, Temnocephalidae) de la Isla Martín García, Buenos Aires, Argentina. Neotropica 43 (109-110): 123-124.

Di Persia, D.H. \& M.S. Radici de Cura. 1973. Algunas consideraciones acerca de los organismos epibiontes desarrollados sobre Ampullariidae. Physis 32 (85): 309-319.

DionI, W. 1967. Temnocephalas uruguayas II. Descripción de Temnocephala talicei $\mathrm{n}$. sp. y notas sobre T. axenos Monticelli (Platyhelmintha). Physis 26 (73): 477-484.

Flecher, L. \& R. Ponce de León. 1983. Observaciones acerca de la regeneracion en Temnocephala iheringi Haswell, 1893, (Platyhelminthes, Turbellaria). Boletín de la Sociedad Zoológica del Uruguay 1: 67-72.

Galigher, A.E. \& E.N. Kozloff. 1971. Essentials of Practical Microtechnique. Philadelphia, Lea \& Febiger, $2^{\text {nd }}$ ed, X+531p.

GonzÁlez. L.E.; R. Ponce de León \& E.S. de Vaio. 1987. Chromosome differences between two species of Temnocephala (Platyhelminthes). Cytobios 49: 85-88.

HASWELL, W.A. 1893. A monograph of the Temnocephaleae, p. 93152. In: J. J. Fletcher (Ed.). Proceedings of the Linnean Society of New South Wales. The Macleay Memorial Volume, p. 93-152.

Humason, G. 1972. Animal Tissue Techniques. San Francisco, W.H. Freeman, $3^{\text {rd }}$ ed., XIV+641p.

HyMAN, L.H. 1955. Miscellaneous marine and terrestrial flatworms from South America. American Museum Novitates

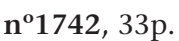


Joffe, B.I.; I.V. Solover \& L.R.G. CANNON. 1995. The structure of the epidermis in Didymorchis (Temnocephalida: Platyhelminthes). Australian Journal of Zoology 43 (6): 631-641.

Martín, P.R.; A.L. Estebenet \& S. BuRela. 2005. Factors affecting the distribution and abundance of the commensal Temnocephala iheringi (Platyhelminthes: Temnocephalidae) among the southernmost populations of the apple snail Pomacea canaliculata (Mollusca: Ampullariidae). Hydrobiologia 545 (1): 45-53.

Moretto, H.J.A. 2001. The resorptive vesicle of Temnocephala jheringi (Temnocephalida). Belgian Journal of Zoology 131 (Suppl. 1): 179-182.

Moretto, H.J.A. \& J. Durquet. 1977. El sistema reproductor en Temnocephala jheringi Haswell, 1893 (Temnocephaloidea), epibionte de Pomacea canaliculata (Scott, 1957) (Mollusca). Physis 37 (93): 75-88.

Odebrecht, C. 2009. Hermann von Ihering e o Guahyba do século XIX. Available online at: http:/www.popa.com.br/docs/ crônicas/ihering_by_manota.html. [Accessed: 12/I/2009].

Pereira, C. \& R. Cuocolo. 1941. Estudos sobre "Temnocephalidae Monticelli, 1899", com estabelecimento de dois novos gêneros australianos e descrição de duas novas espécies neotrópicas. Arquivos do Instituto Biológico 12 (9): 101-127.

Ponce de León, R. 1979. Especies americanas de Temnocephalidea Benham (Platyhelmintha), I. Descripción de Temnocephala rochensis n. sp. de la camara paleal de Pomacea canaliculata (Lamarck). Revista de Biologia del Uruguay 7 (1): 39-48.

PonCE DE León, R. 1989. Description of Temnocephala haswelli n. sp. (Platyhelminthes) from the mantle cavity of Pomacea canaliculata (Lamarck). Journal of Parasitology 75 (4): 524-526.

RomeIs, B. 1948. Mikroskopische Technik. Munchen, Leibniz, $\mathrm{XI}+695 \mathrm{p}$.

Sewell, K.B.; L.R.G. Cannon \& D. Blair. 2006. A review of Temnohaswellia and Temnosewellia (Platyhelminthes: Temnocephalida: Temnocephalidae), ectosymbionts from Australian crayfish Euastacus (Parastacidae). Memoirs of the Queensland Museum 52 (1): 199-280.

Vega, L.A.; M.C. Damborenea; C. Gamarra-Luques; E. Koch; J.A. Cueto \& A. Castro-Vazquez. 2006. Workshop: Biology of Ampullariidae. Facultative and obligate symbiotic associations of Pomacea canaliculata (Caenogastropoda, Ampullariidae). Biocell 30 (2): 367-375.

Volonterio, O. 2007. A new species of Temnocephala (Platyhelminthes, Temnocephalida) and a description of T. axenos from Uruguay. Journal of Natural History 41 (21-24): 1245-1257.

Volonterio, O. \& R. Ponce de León. 2004. The first ultrastructural description of the Haswell cells in Temnocephalidae (Platyhelminthes, Temnocephalida), with insights into their function. Parasitology Research 92 (5): 355-360.

Submitted: 13.V.2009; Accepted: 29.III.2010.

Editorial responsibility: Marcus V. Domingues 